\title{
Perioperative Pulmonary Embolism Prevention and Treatment
}

\author{
Jeff Huang, MD ${ }^{1}$, Yun Lu, Pharm D ${ }^{2}$, Jeffrey Chen ${ }^{3}$ \\ ${ }^{1}$ Anesthesiologists of Greater Orlando \& University of Central Florida, Orlando. FL \\ ${ }^{2}$ Hennepin county medical center, Minneapolis, $\mathrm{MN}$ \\ ${ }^{3}$ University of Central Florida, Orlando, FL
}

\begin{abstract}
All perioperative patients are at an increased risk of pulmonary embolism and venous thromboembolism. Perioperative massive pulmonary embolism (PE) are a significant cause of morbidity and mortality. Clinical outcomes have been shown to be improved by a careful observation, prompt recognition, and aggressive intervention. It is important that healthcare providers recognize perioperative $\mathrm{PE}$ and know prevention and treatment options. Many medical societies have published guideline recommendations for management of PE. In this review, we will focus on perioperative acute PE treatment and prevention to implement guideline recommendations for optimizing management of acute PE.
\end{abstract}

Key words: Pulmonary embolism; perioperative; guideline

\section{Introduction}

Massive perioperative pulmonary embolism (PE) is an uncommon event but significant cause of morbidity and mortality. It is estimated that $\mathrm{PE}$ is responsible for between 150,000 and 200,000 deaths per year in the United States (1). Thirty percent of the deaths from PE take place during the perioperative period (1). The third most prevalent cause of cardiovascular disease is PE after myocardial infarction and cerebrovascular accident (stroke). Several studies have reported the mortality rate of a PE ranging from $15 \%$ to $30 \%$, while mortality rates in a massive PE can reach $30 \%$ to $50 \%$ (2-4). A recent review of more than 3000 mas- sive intraoperative thromboembolic events revealed an overall mortality of $41 \%$ (5).

Surgery increases the risks for perioperative PE. Healthcare providers are responsible for the diagnosis and treatment of perioperative PE. During surgery, PE often first presents with hemodynamic instability and if progressing quickly, can lead to death. It is important that healthcare providers recognize perioperative $\mathrm{PE}$ and know prevention and treatment options. Prompt diagnosis and treatment can save patient lives. In this review, we will focus on perioperative acute PE treatment and prevention.

\section{Diagnosis of an acute PE}

Diagnosis of an acute PE in the perioperative period can be a challenge, but early detection can reduce morbidity. The American Heart Association (AHA) classified and defined acute PE into three classes: massive PE, submassive PE, and low-risk PE (6).

Criteria for massive PE: Acute PE with sustained systolic blood pressure $<90 \mathrm{~mm} \mathrm{Hg}$ for at least 15 minutes or requiring inotropic support, pulselessness, or persistent heart rate $<40 \mathrm{bpm}$ with hemodynamic instability (6).

Criteria for submassive PE: Acute PE systolic blood pressure $\geq 90 \mathrm{~mm} \mathrm{Hg}$ but with either RV dysfunction or myocardial necrosis (6).

$\mathrm{RV}$ dysfunction is diagnosed by the presence of at 
Table 1: AHA recommendations for systemic thrombolysis for acute PE

\begin{tabular}{|l|l|l|}
\hline Recommendations for Systemic Thrombolysis Utilization & Class & Level \\
\hline $\begin{array}{l}\text { Recommended for massive acute PE with acceptable risk of bleeding compli- } \\
\text { cations }\end{array}$ & IIa & B \\
\hline $\begin{array}{l}\text { Consider for submassive acute PE with clinical evidence of adverse progno- } \\
\text { sis (new hemodynamic instability, worsening respiratory insufficiency, severe } \\
\text { RV dysfunction, or major myocardial necrosis) with low risk of bleeding } \\
\text { complications }\end{array}$ & IIb & C \\
\hline $\begin{array}{l}\text { Not recommended for low-risk PE or submassive acute PE with minor RV } \\
\text { dysfunction, minor myocardial necrosis, and if patient is not worsening clini- } \\
\text { cally }\end{array}$ & III & B \\
\hline Not recommended for undifferentiated cardiac arrest & III & B \\
\hline
\end{tabular}

Recommendation class: I: benefits $>>>$ risks, IIa: benefits $>>$ risks, IIb: benefits $\geq$ risks; III: risks $\geq$ benefits. Level of evidence: A: Multiple population evaluated; B: Limited population evaluated; C: Very limited population evaluated

least 1 of the following: RV dilation: apical 4-chamber RV diameter divided by LV diameter $>0.9$ on echocardiography or on CT. BNP $>90 \mathrm{pg} / \mathrm{mL}$. N-terminal pro-BNP $>500 \mathrm{pg} / \mathrm{mL}$; or Electrocardiographic changes such as, new complete or incomplete right bundle-branch block, anteroseptal ST elevation or depression, or anteroseptal T-wave inversion.

Myocardial necrosis is diagnosed by either of the following: (1) troponin I $>0.4 \mathrm{ng} / \mathrm{mL}$ or (2) troponin $\mathrm{T}$ $>0.1 \mathrm{ng} / \mathrm{mL}$.

Criteria for low-risk PE: Acute PE in the absence of criteria for massive or submassive PE (6).

\section{THE TREATMENT OF ACUTE PULMONARY EMBOLISM}

Systemic Thrombolysis

Thrombolytic agents are indicated in patients who are normotensive but with evidence of RV failure or in cases of hemodynamic instability (7). Several societies' guidelines advocate the use of thrombolytic agent in patients with hemodynamic compromise and massive $\mathrm{PE}(6,8)$.

A clinical study including patients with massive PE showed systemic thrombolysis therapy reduced the composite of recurrent PE and mortality, but no difference in mortality alone (9). The results of patients with submassive PE were categorized through random- ized trials. These studies showed the use of systemic thrombolysis in patients with massive or submassive PE can enhance hemodynamic stability and, reduce recurrent $\mathrm{PE}$ and $\mathrm{PE}$-attributed mortality (10).

The most commonly US Food and Drug Administration (FDA approved thrombolytic agents for acute PE include: tPA, alteplase, streptokinase (SK), and urokinase (UK). Other thrombolytic agents without FDA approval include tenecteplase, and reteplase.

All fibrinolytic drugs are enzymes that enhance the conversion of the patient's circulating plasminogen into plasmin. The contraindications include active bleeding; history of intracranial hemorrhage, intracranial cerebrovascular disease, possible aortic dissection, intracranial malignant neoplasm, ischemic stroke within 3 months, recent neurosurgery, recent head trauma(6), and uncontrolled hypertension (11)

Streptokinase should also not be used after 5 days to 12 months of initial use for possible anaphylactic reaction from anti-streptokinase antibodies or in patients with recent streptococcal infections due to possible drug resistance or reduced effects. (12-15). AHA recommendations for systemic thrombolysis for acute PE (6) was shown in Table 1.

\section{Catheter-based therapies}

Catheter-based therapies can (1) quickly ease pul- 
Table 2: AHA recommendation for catheter based therapies and surgical embolectomy for acute PE

\begin{tabular}{|l|l|l|}
\hline Recommendations for Catheter Based Therapies and Surgical Embolectomy & Class & Level \\
\hline Recommended for massive PE with contraindications to fibrinolysis & IIa & C \\
\hline $\begin{array}{l}\text { Recommended for massive PE in patients who are unstable after systemic } \\
\text { fibrinolysis }\end{array}$ & IIa & C \\
\hline $\begin{array}{l}\text { Recommended to safely transfer patient to an institution experienced in either } \\
\text { catheter embolectomy or surgical embolectomy if these procedures are not } \\
\text { available locally }\end{array}$ & IIa & C \\
\hline $\begin{array}{l}\text { Consider for patients with submassive acute PE with clinical evidence of ad- } \\
\text { verse prognosis (new hemodynamic instability, worsening respiratory failure, } \\
\text { severe RV dysfunction, or major myocardial necrosis) }\end{array}$ & IIb & C \\
\hline $\begin{array}{l}\text { Not recommend for low-risk PE or submassive acute PE with minor RV dys- } \\
\text { function, minor myocardial necrosis, and if patient is not worsening clinically }\end{array}$ & III & C \\
\hline
\end{tabular}

monary artery pressure, RV tension, and pulmonary vascular resistance (PVR), (2) improve systemic circulation, and (3) return RV function (6). This treatment is an alternative method to remove pulmonary emboli and is a less invasive approach compared to surgical embolectomy. Catheter-directed therapies include fragmentation of thrombus by pulmonary artery catheter, clot reduction by basket catheter, thrombectomy by percutaneous rheolytic therapy, or pigtail catheter (16). Catheter-directed thrombolysis is considered in cases of unsuccessful systemic thrombolysis, contra- indications to thrombolytic therapy, and when surgical embolectomy is unavailable or not feasible (7).

Potential complications from catheter directed therapies include pulmonary hemorrhage and the risk of cardiac tamponade if the right atria or ventricle are perforated . Similarly, massive pulmonary hemorrhage and death may result from the perforation or dissection of a major pulmonary blood vessel (6).

There are no prospective studies to evaluate catheter based techniques for massive PE (16). A systematic Table 3: PE treatment options

\begin{tabular}{|c|c|c|}
\hline & \multicolumn{2}{|r|}{ Treatment Options } \\
\hline & Systemic Thrombolysis & $\begin{array}{l}\text { Catheter Embolectomy and Fragmentation or } \\
\text { Surgical Embolectomy }\end{array}$ \\
\hline Low-Risk PE & Not Recommended (III-B) & Not Recommended (III-C) \\
\hline Submassive PE & $\begin{array}{l}\text { Recommended only if adverse } \\
\text { prognosis present* (IIb-C) }\end{array}$ & $\begin{array}{l}\text { Recommended only if adverse prognosis pres- } \\
\text { ent* (IIb-C) }\end{array}$ \\
\hline Massive PE & $\begin{array}{l}\text { Recommended (IIa-B) with } \\
\text { acceptable risk of bleeding } \\
\text { complications }\end{array}$ & $\begin{array}{l}\text { Recommended if fibrinolysis contraindicated } \\
\text { or patient remains unstable after fibrinolysis } \\
\text { (IIa-C) }\end{array}$ \\
\hline $\begin{array}{l}\text { Undifferentiated } \\
\text { Cardiac Arrest }\end{array}$ & Not Recommended (III-B) & $\mathrm{N} / \mathrm{A}$ \\
\hline \multicolumn{3}{|c|}{$\begin{array}{l}\text { Recommendation class: I: benefits }>>>\text { risks, IIa: benefits }>>\text { risks, IIb: benefits } \geq \text { risks; III: } \\
\text { risks } \geq \text { benefits. }\end{array}$} \\
\hline \multicolumn{3}{|c|}{$\begin{array}{l}\text { Level of evidence: A: Multiple population evaluated; B: Limited population evaluated; C: } \\
\text { Very limited population evaluated }\end{array}$} \\
\hline
\end{tabular}


review with a total of 348 acute massive PE patients showed that success rate of clinical percutaneous therapy alone was $81 \%$, and when combined with thrombolytic agents was $95 \%$ (17).

\section{Surgical embolectomy}

Surgical embolectomy is considered the final treatment option for acute PE (18). The surgery requires a medi- pulmonary hypertension, or severe hypoxia that could require the use of mechanical circulation supporting devices, and extracorporeal membrane oxygenation (ECMO) (7). AHA recommendation for catheter based therapies and surgical embolectomy for acute PE (6) was shown in Table 2.

PE treatment options were summarized in Table 3.

Table 4: AHA recommendation for placement of IVC filter for acute PE

\begin{tabular}{|l|l|l|}
\hline Recommendations for placement of IVC Filter & Class & Level \\
\hline $\begin{array}{l}\text { Recommended for acute PE with contraindications to anticoagulation or with } \\
\text { active bleeding complications }\end{array}$ & I & B \\
\hline $\begin{array}{l}\text { After placement of an IVC filter, anticoagulation should be resumed promptly } \\
\text { when contraindications to anticoagulation or active bleeding complications } \\
\text { have been resolved }\end{array}$ & I & B \\
\hline $\begin{array}{l}\text { After placement of retrievable IVC filters, patients should be assessed periodi- } \\
\text { cally for filter retrieval within the specific filter's retrieval window }\end{array}$ & I & C \\
\hline $\begin{array}{l}\text { Recommended to place an IVC filter for recurrent acute PE despite therapeutic } \\
\text { anticoagulation }\end{array}$ & IIa & C \\
\hline $\begin{array}{l}\text { Recommended to place a permanent IVC filter for those with a long-term con- } \\
\text { traindication to anticoagulation }\end{array}$ & IIa & C \\
\hline $\begin{array}{l}\text { Consider to place an IVC filter for acute PE with very poor cardiopulmonary } \\
\text { reserve }\end{array}$ & IIb & C \\
\hline $\begin{array}{l}\text { Not recommended to be used routinely as an adjuvant in the treatment of acute } \\
\text { PE }\end{array}$ & III & C \\
\hline
\end{tabular}

an sternotomy and cardiopulmonary bypass. Surgical embolectomy is indicated for acute PE patients with a right atrial thrombus, paradoxical arterial embolism, or a closure of a patent foramen ovale (16). Surgical embolectomy is also indicated for patients who were unsuccessfully treated with thrombolytic agents (16). Significant advances in cardiac surgical techniques have reduced surgical mortality, which is about $6 \%$ currently $(19,20)$. In addition, there is evidence that pulmonary embolectomy can reduce long term mortality $(21,22)$.

Major risks of surgical embolectomy include: injury to the distal branches of the PA during embolectomy that can lead to significant bronchoalveolar hemorrhage (7), inability to wean from cardiopulmonary bypass because of primary RV dysfunction, persistent severe

\section{Vena Caval Filters}

An inferior vena cava (IVC) filter is inserted in patients with acute $\mathrm{PE}$ who can not receive systemic thrombolysis, in patients who experienced major bleeding events, and in patients who are confirmed recurrent $\mathrm{PE}$ after adequate anticoagulation therapy (23).

Data from the U.S. Nationwide Inpatient Sample suggest that cava filters may improve clinical outcome (24). In the PREPIC Trial (Pre'vention du Risque d'Embolie Pulmonaire par Interruption Cave), patients with acute $\mathrm{PE}$ and lower extremities vein thrombosis were randomized into two groups, one group received anticoagulation only, the other group received anticoagulation with IVC filter (25). The results demonstrated that there were no differences in major bleeding, 
postthrombotic chronic venous insufficiency, or mortality rate (25). These clinical data did not support the
Deep vein thrombosis (DVT) occurred in 348, 558 hospitalizations, pulmonary embolism (PE) occurred

Table 5: Modified Caprini assessment model for general surgery thrombotic risk evaluation.

\begin{tabular}{|c|c|c|c|}
\hline 1 Point & 2 Points & 3 Points & 5 Points \\
\hline Age $41-60 y$ & Age $61-74 \mathrm{y}$ & Age $\geq 75 y$ & Stroke $(<1 \mathrm{mo})$ \\
\hline Minor surgery & Arthroscopic surgery & History of VTE & Elective arthroplasty \\
\hline $\mathrm{BMI}>25 \mathrm{~kg} / \mathrm{m}^{2}$ & $\begin{array}{l}\text { Major open surgery } \\
\text { (>45 min) }\end{array}$ & $\begin{array}{l}\text { Family history of } \\
\text { VTE }\end{array}$ & $\begin{array}{l}\text { Hip, pelvic, or leg } \\
\text { fracture }\end{array}$ \\
\hline Swollen legs & $\begin{array}{l}\text { Laparoscopic surgery } \\
\text { (>45 min) }\end{array}$ & Factor V Leiden & $\begin{array}{l}\text { Acute spinal cord } \\
\text { injury }(<1 \mathrm{mo})\end{array}$ \\
\hline Varicose veins & Malignancy & Prothrombin 20210A & \\
\hline Pregnancy or postpartum & $\begin{array}{l}\text { Confined to bed ( }>72 \\
\text { h) }\end{array}$ & Lupus anticoagulation & \\
\hline $\begin{array}{l}\text { History of unexplained } \\
\text { or recurrent spontaneous } \\
\text { abortion }\end{array}$ & $\begin{array}{l}\text { Immobilizing plaster } \\
\text { cast }\end{array}$ & $\begin{array}{l}\text { Anticardiolipin anti- } \\
\text { bodies }\end{array}$ & \\
\hline $\begin{array}{l}\text { Oral contraceptive or hor- } \\
\text { mone replacement }\end{array}$ & Central venous access & $\begin{array}{l}\text { Elective serum homo- } \\
\text { cysteine }\end{array}$ & \\
\hline Sepsis $(<1 \mathrm{mo})$ & & $\begin{array}{l}\text { Heparin-induced } \\
\text { thrombocytopenia }\end{array}$ & \\
\hline $\begin{array}{l}\text { Serious lung disease, } \\
\text { including pneumonia ( }<1 \\
\text { mo) }\end{array}$ & & $\begin{array}{l}\text { Other congenital or } \\
\text { acquired thrombo- } \\
\text { philia }\end{array}$ & \\
\hline \multicolumn{4}{|l|}{$\begin{array}{l}\text { Abnormal pulmonary } \\
\text { function }\end{array}$} \\
\hline \multicolumn{4}{|l|}{$\begin{array}{l}\text { Acute myocardial infarc- } \\
\text { tion }\end{array}$} \\
\hline \multicolumn{4}{|l|}{$\begin{array}{l}\text { Congestive heart failure } \\
(<1 \mathrm{mo})\end{array}$} \\
\hline \multicolumn{4}{|l|}{$\begin{array}{l}\text { History of inflammatory } \\
\text { bowel disease }\end{array}$} \\
\hline Medical patient at bed rest & & & \\
\hline
\end{tabular}

From: Gould MK, Garcia DA, Wren SM, et al. Prevention of vte in nonorthopedic surgical patients Chest 2012;141(2_suppl):e227S-e277S. Reproduced with permission from The American College of Chest Physicians

Score 0 , very low risk; score 1-2, low risk; score 3-4, moderate risk; score $\geq 5$, High risk

use of retrievable IVC filters in patients with acute PE.

Complications of IVC could include the caval wall penetration or the right side heart embolism. AHA recommendations for placement of IVC filter for acute PE (6) was shown in Table 4.

\section{Prevention}

in 277, 549 hospitalizations, and concomitant DVT and PE occurred in 78, 511 hospitalizations each year (26). In surgical patients, it was estimated that 15 percent were at a moderate risk, 24 percent were at a high risk, and 17 percent were at a very high risk for venous thromboembolism (VTE includes both deep vein thrombosis and pulmonary embolism) (27). 
The National Quality Forum, the Joint Commission on Accreditation of Health Care Organizations, the Surgical Care Improvement Project, the Office of the Surgeon General of the United States, the Centers for Medicine and Medicinal Services, all have initiatives for VTE prophylaxis.

The American College of Chest Physicians (ACCP) published a series of VTE guidelines. A very important change in the ACCP 2012 guideline for the risk of PE with surgery is the emphasis in individualized assessment (28-30). VTE perioperative evaluation should include the category and scope of surgery or trauma, length of hospitalization, a history of previous VTE or cancer, immobility, recent sepsis, presence of a central venous access device, pregnancy or the postpartum period, and inherited or acquired hypercoagulable states. All medical decisions should be made based on the balance between the risk of VTE and risk of major bleeding in the consideration of available literature reports.

Perioperative patients can be divided in to four different risks categories of VTE, patient with high risks, moderate risks, low risks and very low risks. (28-30) (Table 5).

High risk patients - Patients undergoing general and abdominal-pelvic surgery with a Caprini score of 5 or more, or those undergoing plastic and reconstructive surgery with a Caprini score of 7 to 8 are considered as high risk patients. (29-31) The estimated baseline risk of VTE without prophylaxis is estimated to be approximately 6 percent. Examples of patients in the high-risk group are those undergoing majorjoint arthroplasty, pelvic/hip fracture surgery, colorectal surgery, major trauma, spinal cord injury, or cancer surgery. (28-30)

The VTE prophylaxis protocol for patients with high risk patients, recommends the use of either medication or physical methods that are effective for DVT prophylaxis and is considered as a primary prevention approach. Early detection and treatment of subclinical venous thrombosis are classified as secondary prevention. Primary prophylaxis is preferred and is more cost effective than treatment after a VTE. (27)

With all primary VTE prevention in patients with high risks without major bleeding risk, pharmacology prevention is preferred. $(30,31)$, these agents include low-molecular-weight heparin; fondaparinux; dabigatran, apixaban, rivaroxaban, endoxaban; low-dose unfractionated heparin; adjusted-dose vitamin $\mathrm{K}$ antagonist; aspirin (all Grade I B) for a minimum of 10 to 14 days. (28)

Patients at high risk for VTE undergoing abdominal or pelvic surgery for cancer, ACCP recommends extended-duration, postoperative, pharmacologic prophylaxis for 4 weeks with LMWH over limited-duration prophylaxis (Grade I B). (30)

Patients with high risk of VTE undergoing orthopedic surgery are suggested to be on VTE prophylaxis for up to 35 days (Grade II B). (28) In patients at increased bleeding risk, ACCP suggests an IPCD (Intermittent Pneumatic Compression Device) or no prophylaxis. (28)

For patients with isolated lower extremity injuries requiring leg immobilization, ACCP suggests no thromboprophylaxis (Grade IIB). For patients undergoing knee arthroscopy without a history of VTE, thromboprophylaxis is not suggested either (Grade IIB). (28)

Patients with a high risk for VTE who are at high risk for major bleeding complications, the ACCP recommends the use of mechanical prophylaxis, preferably with IPC, over no prophylaxis until the risk of bleeding diminishes and prophylaxis with medication can be initiated (Grade IIC). (30)

Moderate risk patients - Surgical patients undergoing general and abdominal-pelvic surgery with a Caprini score of 3 to 4 , or those undergoing plastic and reconstructive surgery with a Caprini score of 5 to 6 carry a moderate risk of thrombotic events. Their estimated baseline risk of VTE in the absence of prophylaxis is estimated to be approximately 3 percent. Examples of these group of patients include patients with general gynecologic, urologic, thoracic, ankle fracture, or neurosurgical procedures (28-30).

For patient with moderate risk of VTE without major risk of bleeding: low-molecular-weight heparin (LMWH) (Grade IIB), low-dose unfractionated heparin (Grade IIB), or mechanical prophylaxis with IPC 
Table 6: VTE prevention

\begin{tabular}{|c|c|c|c|}
\hline & Classification & Primary Prevention & $\begin{array}{l}\text { Prevention with high risk for } \\
\text { major bleeding complications }\end{array}$ \\
\hline High Risk & $\begin{array}{l}\text { General/Abdominal-Pelvic Sur- } \\
\text { gery with Caprini score of } \geq 5 \\
\text { OR } \\
\text { Plastic/Reconstructive Surgery } \\
\text { with Caprini score of } 7-8\end{array}$ & $\begin{array}{l}\text { Pharmacology with LMW } \\
\text { Heparin, fondaparinux, dabig- } \\
\text { atran, apixaban, rivaroxaban, } \\
\text { endoxaban, low dose un- } \\
\text { fractionated heparin, adjust- } \\
\text { ed-dose vitamin K antagonist, } \\
\text { aspirin (Grade IB) for a } \\
\text { minimum of 10-14 days } \\
\end{array}$ & $\begin{array}{l}\text { Mechanical Prophylaxis, prefer- } \\
\text { ably with IPC, over no pro- } \\
\text { phylaxis until risk of bleeding } \\
\text { diminishes and pharmacologic } \\
\text { prophylaxis may be initiated } \\
\text { (Grade IIC) }\end{array}$ \\
\hline Moderate Risk & $\begin{array}{l}\text { General/Abdominal-Pelvic Sur- } \\
\text { gery with Caprini score of 3-4 } \\
\text { OR } \\
\begin{array}{l}\text { Plastic/Reconstructive Surgery } \\
\text { with Caprini score of 5-6 }\end{array}\end{array}$ & $\begin{array}{l}\text { Pharmacology with } \\
\text { LMWH (Grade IIB), low-dose } \\
\text { unfractionated heparin (Grade } \\
\text { IIB), or mechanical } \\
\text { prophylaxis with IPC (Grade } \\
\text { IIC) are recommended over } \\
\text { no prophylaxis. }\end{array}$ & $\begin{array}{l}\text { Mechanical prophylaxis, } \\
\text { preferably with IPC until the } \\
\text { risk of bleeding diminishes and } \\
\text { pharmacologic prophylaxis may } \\
\text { be initiated (Grade IIC) }\end{array}$ \\
\hline Low Risk & $\begin{array}{l}\text { General/Abdominal-Pelvic Sur- } \\
\text { gery with Caprini score of 1-2 } \\
\text { OR } \\
\text { Plastic/Reconstructive Surgery } \\
\text { with Caprini score of 3-4 }\end{array}$ & $\begin{array}{l}\text { Mechanical prophylaxis, } \\
\text { preferably with IPC over no } \\
\text { prophylaxis (Grade IIC) }\end{array}$ & $\begin{array}{l}\text { Mechanical prophylaxis, prefer- } \\
\text { ably with IPC over no prophy- } \\
\text { laxis (Grade IIC) }\end{array}$ \\
\hline Very Low Risk & $\begin{array}{l}\text { General/Abdominal-Pelvic Sur- } \\
\text { gery with Caprini score of } 0 \\
\text { OR } \\
\begin{array}{l}\text { Plastic/Reconstructive Surgery } \\
\text { with Caprini score of } 0-2\end{array}\end{array}$ & $\begin{array}{l}\text { Early Ambulation recom- } \\
\text { mended. } \\
\text { No specific pharmacologic } \\
\text { (Grade IB) or mechanical } \\
\text { (Grade IIC) recommended }\end{array}$ & $\begin{array}{l}\text { Early Ambulation recommend- } \\
\text { ed. No specific pharmacologic } \\
\text { (Grade IB) or mechanical } \\
\text { (Grade IIC) recommended }\end{array}$ \\
\hline
\end{tabular}

LMWH : low-molecular-weight heparin

(Grade IIC) are recommended over no prophylaxis.

(30) For patients at moderate risk for VTE who are at high risk for major bleeding complications or those in whom the risk of bleeding is severe, the ACCP recommends mechanical prophylaxis, preferably with IPC until the risk of bleeding diminishes and pharmacologic prophylaxis may be initiated (Grade II C). (31)

Low risk patients - Patients undergoing general and abdominal-pelvic surgery with a Caprini score of 1 to 2 , or those undergoing plastic and reconstructive surgery with a Caprini score of 3 to 4 are included in the low risk group for thrombotic events. Their estimated baseline risk of VTE without any prophylaxic treatmentis estimated to be approximately 1.5 percent. Clinical data on this group is scarce but the recommendation by the ACCP include mechanical prophy- laxis, preferably with intermittent pneumatic compression (IPC) over no prophylaxis (Grade II C). (30)

Very low risk patients - patients undergoing general and abdominal-pelvic surgery with a Caprini score of zero, and those undergoing plastic and reconstructive surgery with a Caprini score of zero to two carries very low risk of thrombotic events with estimated risk less than 0.5 percent without prophylaxis. There is no clinical data to demonstrate the efficacy of VTE prophylaxis in this group. Early ambulation is recommended. (30)

An important update in the 2012 ACCP guideline is for patients in all risk groups, that recommend that an inferior vena cava filter should not be used as the primary VTE prevention method (Grade II C) and that venous compression ultrasonography should not be 
executed (Grade II C)(28-30).

VTE Prophylaxis should be started either preoperatively or promptly postoperatively, and continued at least until the patient is fully ambulatory based on FDA approved labeling. VTE prevention was summarized in Table 6.

\section{Acknowledgements}

None

\section{Disclosure of Funding: None}

Conflict Interests Disclosure: The authors have no conflicting interests to disclose.

Corresponding Authors: Jeff Huang, MD.

Anesthesiologists of Greater Orlando \& University of Central Florida, Orlando. FL Email: jeffhuangmd@ gmail.com

Editor: Jun-Ming Zhang,MD, MSc, Professor and Vice Chair for Research, Department of Anesthesiology, University of Cincinnati. jun-ming. zhang@uc.edu

\section{Additional publication details}

Journal short name: Transl Perioper \& Pain Med Received Date: Jan 23, 2017

Accepted Date: April 3, 2017

Published Date: May 4, 2017

Transl Perioper \& Pain Med 2017; 2(3):1-9

\section{Citation and Copyright}

Citation: Huang J, Lu Y, Chen J. Perioperative Pulmonary Embolism Prevention and Treatment. Transl Perioper \& Pain Med 2017; 2(3): 1-9

Copyright: (C) 2017 Huang J. et al.This is an open-access article distributed under the terms of the Creative Commons Attribution License, which permits unrestricted use, distribution, and reproduction in any medium, provided the original author and source are credited.

\section{References}

1. Galson SK. The surgeon general's call to action to prevent deep vein thrombosis and pulmonary embolism (accessed online May 15, 2016 at: www.surgeongeneral.gov/topics/deepvein/calltoaction/call-to-action-ondvt-2008.pdf.

2. Brembilla-Perrot B, Miljoen H, Houriez P, et al. Causes and prognosis of cardiac arrest in a population admitted to a general hospital; a diagnostic and therapeutic problem. Resuscitation 2003;58:319-27.

3. Torbicki A, Gali N, Covezzoli A, et al. Right heart thrombi in pulmonary embolism. Results from the International Cooperative Pulmonary Embolism Registry. J Am Coll Cardiol 2003;41:2245-51.

4. Dalen JE, Alpert JS. Natural history of pulmonary embolism. Prog Cardiovasc Dis 1975;17:259.

5. Visnjevac O, Lee K, Bulatovic R, et al. Outcomes based systematic review for management of massive intra-cardiac or pulmonary thrombotic emboli during surgery. Heart Lung Vessel 2014; 6(1):24-32

6. Jaff MR, McMurtry MS, Archer SL, et al. Management of massive and submassive pulmonary embolism, iliofemoral deep vein thrombosis, and chronic thromboembolic pulmonary hypertension: a scientific statement from the American Heart Association. Circulation 2011;123:1788-830

7. Cox JC, Jablons DM. Operative and Perioperative Pulmonary Emboli. Thorac Surg Clin 25 (2015) 289-299

8. Torbicki A, Perrier A, Konstantinides S, et al. Guidelines on the diagnosis and management of acute pulmonary embolism: the Task Force for the Diagnosis and Management of Acute Pulmonary Embolism of the European Society of Cardiology (ESC). Eur Heart J 2008;29:2276-315.

9. Becattini C, Vedovati MC, Agnelli G. Prognostic value of troponins in acute pulmonary embolism. A meta-analysis. Circulation 2007; 116:427-33.

10. Chatterjee S, Chakraborty A, Weinberg I, et al. Thrombolysis for pulmonary embolism and risk of allcause mortality, major bleeding, and intracranial hemorrhage: a meta-analysis. JAMA 2014;311:2414-21.

11. O'Gara PT, Kushner FG, Ascheim DD, Casey DE Jr, Chung MK, de Lemos JA, et al. 2013 ACCF/AHA guideline for the management of ST-elevation myocardial infarction: executive summary: a report of the American 
College of Cardiology Foundation/American Heart Association Task Force on Practice Guidelines. Circulation. 2013;127(4):529-55

12. McGrath KG, Patterson $\mathrm{R}$ “Anaphylactic reactivity to streptokinase.” JAMA 1984; 252: 1314-7

13. Tio RA, Voorbij RH, Enthoven R “Adult respiratory distress syndrome after streptokinase." Am J Cardiol 1992; $70: 1632-3$

14. Dykewicz MS, Patterson R "Serum sickness from streptokinase.” Am Heart J 1988; 115 : 1338-9

15. Noel J, Rosenbaum LH, Gangadharan V, Stewart J, Galens G "Serum sickness-like illness and leukocytoclastic vasculitis following intracoronary arterial streptokinase." Am Heart J 1987; 113 : 395-7

16. Kearon C, Kahn SR, Agnelli G, Goldhaber S, Raskob GE, Comerota AJ; American College of Chest Physicians. Antithrombotic therapy for venous thromboembolic disease: American College of Chest Physicians Evidence-Based Clinical Practice Guidelines (8th Edition) CHEST 2008; 133:454S-545S

17. Skaf E, Beemath A, Siddiqui T, Janjua M, Patel NR, Stein PD. Catheter-tip embolectomy in the management of acute massive pulmonary embolism. Am J Cardiol. 2007;99:415-420.

18. Jaber WA, Fong PP, Weisz G, Lattouf O, Jenkins J, Rosenfield K, Rab T, Ramee S. Acute Pulmonary Embolism: With an Emphasis on an Interventional Approach. J Am Coll Cardiol 2016;67:991-1002

19. Stulz P, Schläpfer R, Feer R, et al. Decision making in the surgical treatment of massive pulmonary embolism. Eur J Cardiothorac Surg 1994; 8:188-93.

20. Yalamanchili K, Fleisher AG, Lehrman SG, et al. Open pulmonary embolectomy for treatment of major pulmonary embolism. Ann Thorac Surg 2004;77:819-23.

21. Digonnet A,Moya-Plana A, Aubert S, et al. Acute pulmonary embolism: a current surgical approach. Interact Cardiovasc Thorac Surg 2007;6:27-9.

22. Leacche M, Unic D, Goldhaber SZ, et al. Modern surgical treatment of massive pulmonary embolism: results in 47 consecutive patients after rapid diagnosis and aggressive surgical approach. J Thorac Cardiovasc Surg 2005;129:1018-23.

23. Konstantinides SV, Torbicki A, Agnelli G, et al.
2014 ESC guidelines on the diagnosis and management of acute pulmonary embolism. Eur Heart J 2014;35:3033-69, 3069a-3069k.

24. Stein PD, Matta F, Keyes DC, et al. Impact ofvena cava filters on in-hospital case fatality rate from pulmonary embolism. Am J Med 2012;125: 478-84.

25. Decousus H, Leizorovicz A, Parent F, Page Y, Tardy B, Girard P, Laporte S, Faivre R, Charbonnier B, Barral FG, Huet Y, Simonneau G. A clinical trial of vena caval filters in the prevention of pulmonary embolism in patients with proximal deep-vein thrombosis: Pre'vention du Risque d'Embolie Pulmonaire par Interruption Cave Study Group. N Engl J Med. 1998;338:409-415.

26. Ho KM, Bham E, Pavey W Incidence of Venous Thromboembolism and Benefits and Risks of Thromboprophylaxis After Cardiac Surgery: A Systematic Review and Meta-Analysis J Am Heart Assoc. 2015;4(10):e002652

27. Anderson FA Jr, Zayaruzny M, Heit JA, et al. Estimated annual numbers of US acute-care hospital patients at risk for venous thromboembolism. Am J Hematol 2007; $82: 777$.

28. Falck-Ytter Y, Francis CW, Johanson NA, et al. Prevention of VTE in Orthopedic Surgery Patients: Chest. 2012; 141(2_suppl):e278S-e325S.

29. Schiff RL, Kahn SR, Shrier I, et al. Identifying Orthopedic Patients at High Risk for Venous Thromboembolism Despite Thromboprophylaxis Chest. 2005; 128(5):3364-3371.

30. Gould MK, Garcia DA, Wren SM, et al. Prevention of vte in nonorthopedic surgical patients Chest 2012;141(2 suppl):e227S-e277S. 